\title{
$\mathrm{Na}$ 冷却高速炉の建屋配置を対象とした 3 次元津波解析*
}

\section{Three-Dimensional Tsunami Analysis for the Plot Plan of a Sodium-Cooled Fast Reactor Plant}

\author{
Satoshi HAYAKAWA, Osamu WATANABE, Kei ITO*2 and Tomohiko YAMAMOTO \\ *2 Japan Atomic Energy Agency \\ 4002 Narita, Oarai-machi, Higashi-ibaraki-gun, Ibaraki, 311-1393 Japan
}

\begin{abstract}
As the practical evaluation method of the effect of tsunami on buildings, the formula of tsunami force has been used. However, it cannot be applied to complex geometry of buildings. In this study, to analyze the effect of tsunami on the buildings of sodium-cooled fast reactor plant more accurately, three-dimensional tsunami analysis was performed. In the analysis, VOF (Volume of Fluid) method was used to capture free surface of tsunami. At the beginning, it was confirmed that the tsunami experiment results was reproduced by VOF method accurately. Next, the three-dimensional tsunami analysis was performed with VOF method to evaluate the flow field around the buildings of the plant from the beginning of the tsunami until the backwash of that.
\end{abstract}

Key Words : Tsunami Analysis, Tsunami Force, VOF, Fast Reactor Plant

\section{1. 緒言}

東北地方太平洋沖地震以降，津波の影響評価の重要性は増している．陸上の構造物に対寸る津波の影響評価に は津波荷重算定式(1)が多く用いられるが，対象となる構造物が複雑な形状，配置をとる場合に適切な評価を得る ことは難しい，それに対し，構造物の配置を模擬した空間内での過渡変化を求める津波解析ならば津波溯上時の 複雑な流れや津波荷重について時間を追って詳細に評価することができる，ただし，広範な領域を対象にしなけ ればならない津波解析では多大な計算資源が必要となるため, その多くに平面 2 次元解析と呼ばれる, 高さ方向 に積分した水平面内の流量について運動量則を解き，2 次元格子内での質量保存則から格子上の水位変化を求め る手法が用いられる。しかし，津波遡上時に護岸や構造物を乗り越えるような流れでは 3 次元性を考慮すべきで あるし，計算機能力の向上により 3 次元解析を現実的な範囲で行える状況にある. 本研究では，一般的な構造物 の津波影響評価に適用可能な 3 次元解析手法を $\mathrm{Na}$ 冷却高速炉の建屋に適用寸ることとし，プラント配置計画を 基に作成した解析モデルに沖合から津波を入射させ, 護岸を越えて遡上する津波の 3 次元解析を行った.

\section{2. 津波試験解析}

$\mathrm{Na}$ 冷却高速炉建屋の 3 次元津波解析には自由液面を追跡できる VOF（Volume of Fluid）法を用いた. VOF 法の 津波解析一の適用性については既に検討(2)されているが，本研究では表 1 に示寸解析手法を採用したため，既存 の検討とは差分スキーム等で異なる，そこで，同一の津波試験 ${ }^{(3)}$ を対象とした解析を行って本手法の津波解析一 の適用性を確認した後, Na 冷却高速炉建屋の解析に進むことにした.

解析対象の津波試験は実スケールの 1/200 程度の規模を想定したもので，長さ約 $11 \mathrm{~m} ，$ 幅約 $7 \mathrm{~m}$ の試験装置を 使用し，陸域に津波荷重を測定するための $10 \mathrm{~cm}$ 角の建屋の模型群を配置して，津波の沿岸における浅水変形か

\footnotetext{
* 原稿受付 2013 年 8 月 30 日

*1 三菱 FBR システムズ (株)（厂150-0001 東京都渋谷区神宮前 2-34-17）

*2 正員, (独) 日本原子力研究開発機構（干311-1393 茨城県東茨城郡大洗町成田町 4002）

*3 (独) 日本原子力研究開発機構

E-mail: ito.kei@jaea.go.jp
} 


\section{ら陸上での遡上までが再現された.}

解析では試験体系が沖側から見て左右対称であることから, 図 1 に示寸ように左半分の領域についてモデル化 した．文献(2) と同様に六面体メッシュを用い，建屋周辺に $10 \mathrm{~mm}$ の細かなメッシュを配置し，そこから外側に向 けてメッシュサイズを拡大していき（拡大率約 1.05 1.2), 約 38 万メッシュに分割した. 図 2 に津波荷重の解析 結果（青実線）を文献 ${ }^{(2)}$ の試験結果（丸印）と解析結果（赤実線）の双方と比較して示す. 本解析結果は試験結 果及び文献 (2)の解析結果とほぼ同等であり，津波解析への適用性に問題ないと判断した.

Table 1 Analysis condition

\begin{tabular}{|l|l|l|}
\hline CFD code & \multicolumn{2}{|l|}{ FLUENT 14.0 } \\
\hline Turbulence model & RNG k- $\varepsilon$ model \\
\hline Wall condition & Standard wall function \\
\hline Time discretization scheme & Momentum, $\mathrm{k}$ and $\varepsilon$ & Implicit Euler scheme \\
\cline { 2 - 3 } & VOF & $\begin{array}{l}\text { Explicit Euler scheme } \\
\text { Maximum Courant number } 0.25\end{array}$ \\
\hline Space discretization scheme & Momentum, $\mathrm{k}$ and $\varepsilon$ & Second-order upwind scheme \\
\cline { 2 - 3 } & VOF & Geometry-reconstruct scheme \\
\hline
\end{tabular}

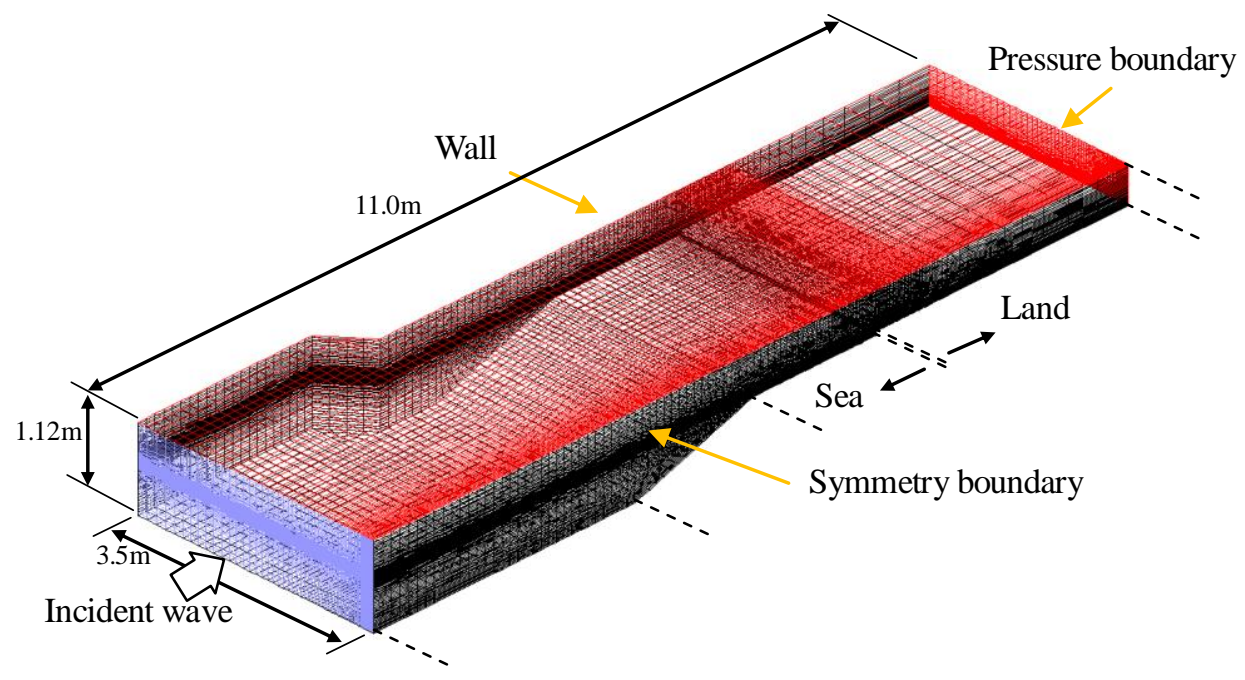

Fig.1 Analysis model of the experiment

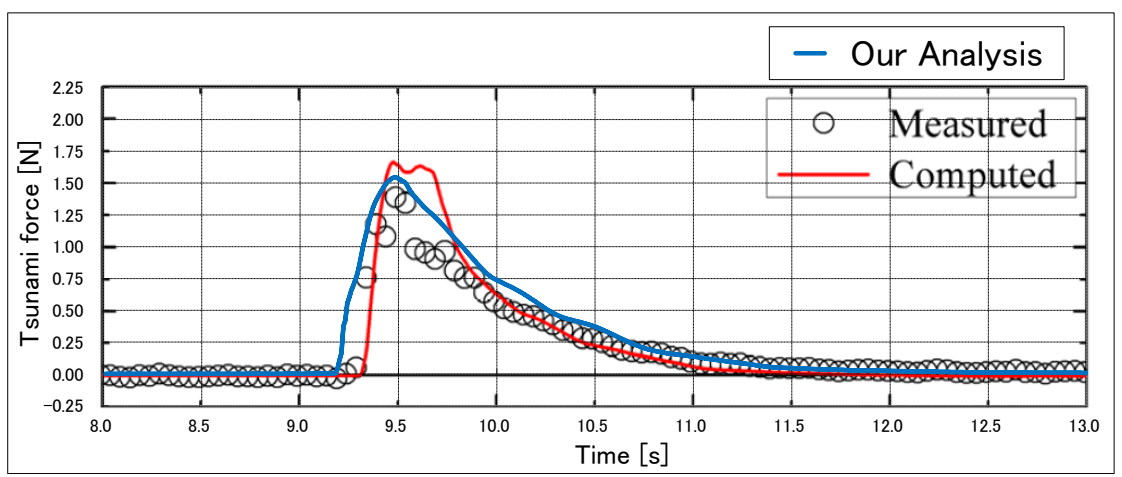

Fig.2 Tsunami force on the obstacle of the experiment 


\section{3. $\mathrm{Na}$ 冷却高速炉建屋の 3 次元津波解析}

図 3 に想定した $\mathrm{Na}$ 冷却高速炬建屋の 3 次元配置を示寸. 解析対象範囲は建屋背面の法面から津波を入射させ る防波堤の $500 \mathrm{~m}$ 沖（以下 $500 \mathrm{~m}$ 沖と呼ぶ）まで，及び後述の反射波考慮のため $500 \mathrm{~m}$ 沖から $100 \mathrm{~km}$ 沖までとし た. また, 幅は 1000m, 初期水位を基準に建屋地盤面は+10m, 防波堤より陸側の海底は-10m, 沖側の海底は-20m, 上空は+80m までとした．両側面は対称境界，地表面等の固体表面は乱流状態を想定して標準壁関数を適用し， 上空面は圧力一定境界とした.

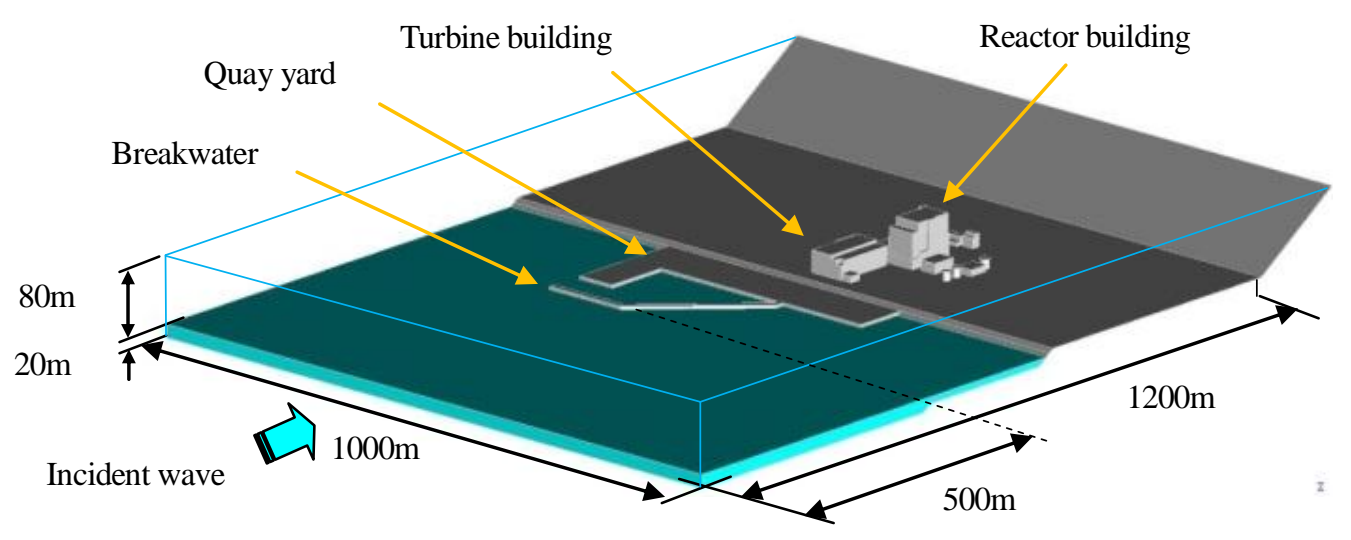

Fig.3 Analysis model of the sodium-cooled fast reactor plant

$500 \mathrm{~m}$ 沖での津波の入射に流速境界条件を用いると陸からの反射波が再反射し非現実的になるため，そのまま 沖側に通過できるように質量ソース及び運動量ソースで波を発生させる方法 ${ }^{(4)}$ を採った. また, モデル端は $100 \mathrm{~km}$ 沖まで離し，再反射が計算時間内に $500 \mathrm{~m}$ 沖まで戻って来ないようにした．津波波形は観測值として残っている 東北地方太平洋沖地震時の女川原子力発電所での波形を参考に, 波高約 $17.6 \mathrm{~m}$ と $25.2 \mathrm{~m}$ の津波解析を行った. 図 4 に，女川の観測波形と解析結果の $500 \mathrm{~m}$ 沖の波形を示す.

解析体系のメッシュ分割は前述の津波試験解析に倣うこととした.メッシュ形状は津波試験解析と同様に六面 体とした. 津波試験解析では約 $60 \mathrm{~mm}$ の波高に対し建屋周辺に $10 \mathrm{~mm}$ （波高に対する比は 1/6）のメッシュを配置 しており，その解像度を確保するため $17.6 \mathrm{~m}$ の波高に対し建屋周辺に $2 \mathrm{~m}$ （波高に対する比は $1 / 8.8$ ）のメッシュ を配置した. 現実的な時間で計算可能なメッシュ数とするため, 津波試験解析と同様に建屋周辺から外側に向け てメッシュサイズを拡大していき（拡大率約 1.05〜 1.2), 総メッシュ数を約 460 万とした. 建屋から離れた津波 入射位置におけるメッシュサイズについて比較すると, 津波試験解析では約 $12 \mathrm{~m}$ の波長に対し約 $130 \mathrm{~mm}$ (波長 に対する比は 1/92）であるのに対し，本解析モデルでは約 $25 \mathrm{~km}$ の波長に対し約 $30 \mathrm{~m} （$ 波長に対する比は 1/833） であり，津波試験解析での解像度は確保できている．また，解析手法には津波試験解析と同じ表 1 に挙げたもの を適用した。

図 5 には波高 $17.6 \mathrm{~m}$ の場合の浸水深と単位幅当たりの津波荷重の時間変化を示す．図 6 には浸水深のコンター と水表面での流速ベクトルを示す. 原子炉建屋前面 ( $\mathrm{A}$ 点) での初期の浸水深及び津波荷重は建屋から離れた $\mathrm{B}$, $\mathrm{C}$ 点よりも高く推移する．これは建屋前面に津波が当たり動圧が静圧に変化したためである．この時には建屋前 面側は浸水深が高く背面側は浸水深が低いため, 浸水深の低い領域に向かう速い流れが生じる. 図 6 の流速べク トル図より 990 秒の時点で最大 $10 \mathrm{~m} / \mathrm{s}$ 程度の流速が生じていることが分かる．また，建屋背面の流れが回り込む ようなところには渦が発生しており，周辺設備については建屋周りの速い流れや渦等に配慮する必要があると考 える. 約 1020 秒の時点では法面からの反射波が $\mathrm{A} \sim \mathrm{C}$ 点に到達し浸水深が急激に上昇するが，その後は $\mathrm{A} \sim \mathrm{C}$ 点 の浸水深の変化はほぼ同様である. 図 6 の 990 秒時点での浸水深コンターには建屋背面から背後の法面にかけて 反射波が重なり水位の上昇した領域が見られる，流速ベクトル図よりその領域の流速は遅いことが分かるが，そ 
れは入射波と反射波の流速が打ち消し合っているためであり，そこでの動圧は小さい. 約 1110 秒の時点では浸水 深はほぼピークになり津波荷重は最大となる。

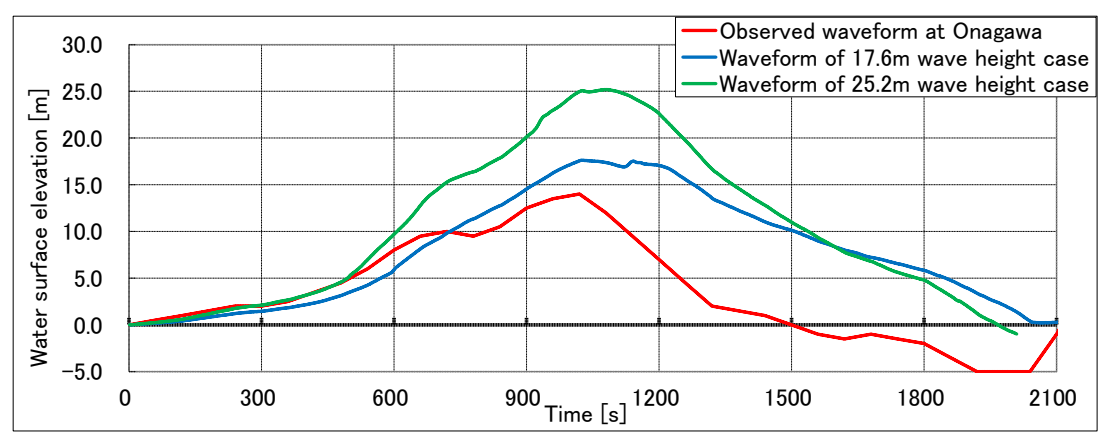

Fig.4 Tsunami waveform

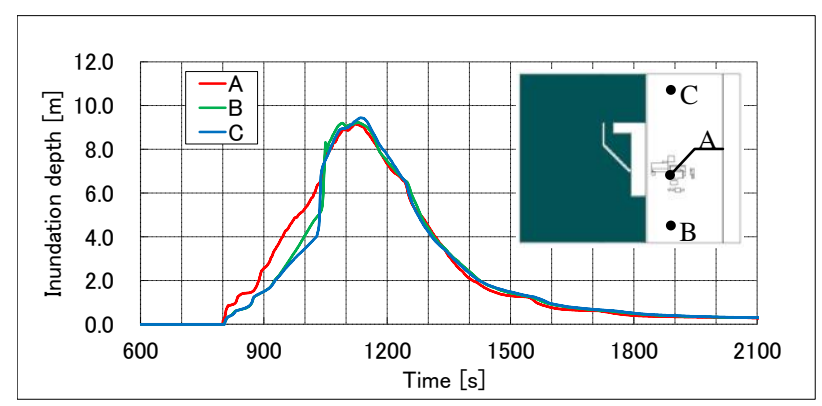

(a) Inundation depth

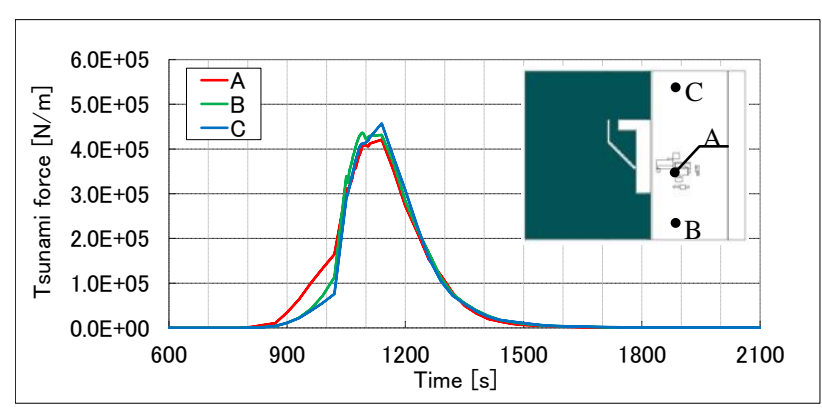

(b) Tsunami force per unit width

Fig.5 Temporal variation of inundation depth and tsunami force
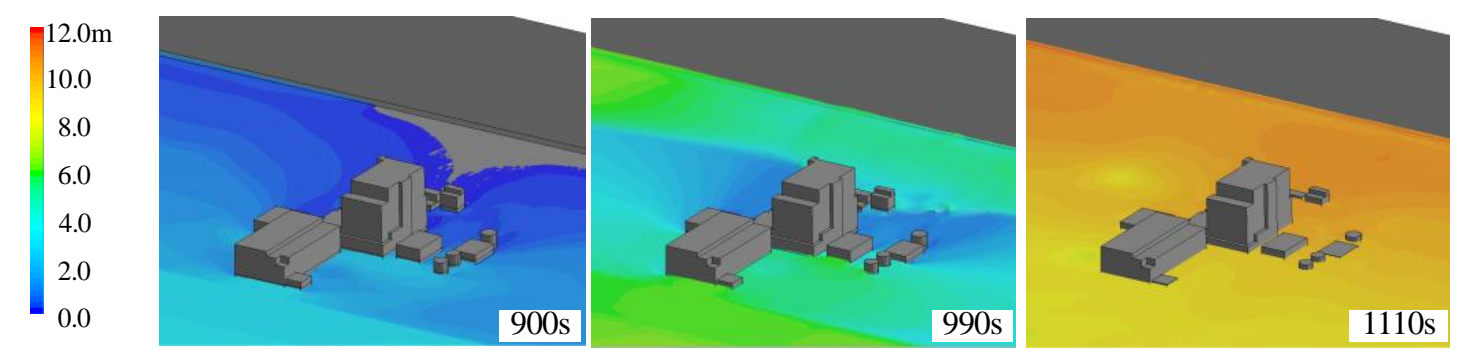

$10.0 \mathrm{~m} / \mathrm{s}$
8.0
6.0
4.0
2.0
0.0
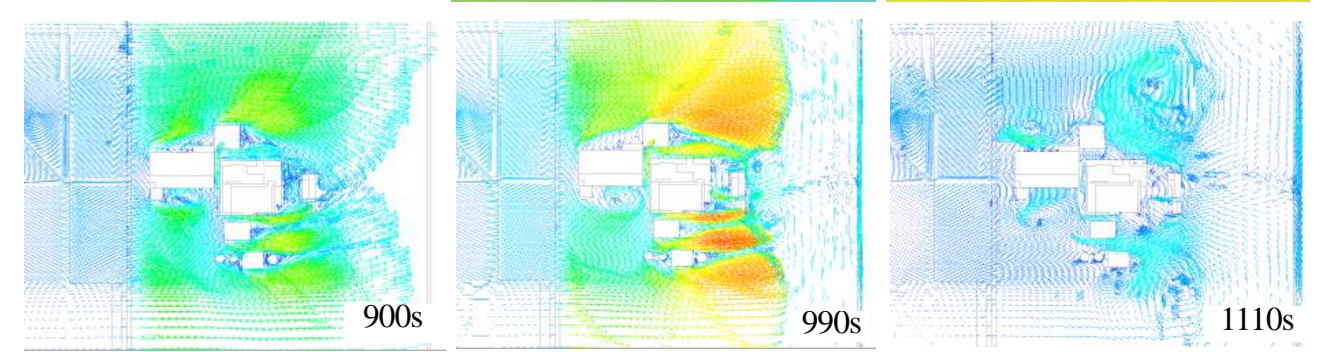

Fig.6 Inundation depth and velocity vector at water surface

本解析結果を基に津波荷重算定式から得られる津波荷重について考察すると, 反射波到達前（図 5 の 1020 秒以 前) では $\mathrm{A}$ 点の浸水深は建屋のない $\mathrm{B}, \mathrm{C}$ 点の約 $1.5 \sim 2$ 倍であり, 建屋のない場合に生じる浸水深の 3 倍の深さ で荷重を算定する津波荷重算定式で保守的に評価できることが分かる. しかし, 本解析の場合には最大津波荷重 は反射波が重なった後の動圧が小さく静圧支配の状況で生じるため, 最大津波荷重発生時での建屋のない B, C 
点における浸水深の 3 倍では過度に保守的となる．ただし，フルード数で整理された津波荷重算定式 ${ }^{(5)} の$ 場合に は3 倍ではなく, フルード数の関数として定義された倍率が設定され，動圧が小さくフルード数が 0 に近いとそ の倍率は 1 に近い值となり本解析の評価に一致する.

波高を $17.6 \mathrm{~m}$ から $25.2 \mathrm{~m}$ に高くした場合には，流速が速いために現象は短くなるが，浸水深及び津波荷重が波 高に応じて増加する結果となり, 変則的な現象は見られなかった。

なお，サイトの地形が確定した段階では以下の解析方法を採る必要があると考える. 本解析では想定した地形 に対し女川の観測波形を参考にした津波波形を入射させたが，波源からの平面 2 次元解析結果を利用して沖合で の津波波形を与えるようにする. この場合, (1)平面 2 次元解析結果を基に 3 次元モデルの境界における入射波を 分離, (2)建屋のない 3 次元モデルにより (1)の入射波が適切であることを確認, (3)建屋のある 3 次元モデルに(2)で 確認した入射波を適用して津波解析を行い，建屋への津波荷重を評価するという手順を踏むことになる.

\section{4. 結}

$\mathrm{Na}$ 冷却高速炉の建屋配置を対象とした 3 次元津波解析を行った，その結果から，建屋周りには最大約 $10 \mathrm{~m} / \mathrm{s}$ の速い流れが生じるとともに建屋背面の流れが回り込むようなところには渦が発生し，周辺設備についてはこの 建屋周りの速い流れや渦等に配慮寸る必要があることが分かった．本解析の場合には反射波が重なって重複波と なった後に浸水深がピークとなり，入射と反射の流速が打ち消し合い動圧のほとんどない静圧支配の状態で最大 津波荷重が発生することが分かった．また，本解析を通して建屋周りを３次元でモデル化した津波解析により $\mathrm{Na}$ 冷却高速炉建屋に作用する荷重を評価できる見通しを得た。

\section{文献}

（1）朝倉良介，岩瀬浩二，池谷 毅，高尾 誠，金戸俊道，藤井直樹，大森政則，“護岸を越流した津波による波力に 関する実験的研究”, 海岸工学論文集, Vol. 47 (2000), pp. 911-915.

（2）中村友昭，水谷法美，藤間功司，“遡上津波の変形と陸上構造物に作用する津波力に関する 3 次元数值シミュレー ション”，ながれ，Vol.29, No. 2 (2010), pp. 107-117.

(3) チャルレス シマモラ, 鴫原良典, 藤間功司, “建物群に作用する津波波力に関する水理実験”，海岸工学論文集， Vol. 54 (2007), pp. 831-835.

（4）山野貴司，有川太郎，川崎浩司，小竹康夫，秋山 実， “3 次元数值波動水槽 CADMAS-SURF/3D 一の造波ソー スの導入とその妥当性”, 土木学会論文集 B2 (海岸工学), Vol. 66, No. 1 (2010), pp. 6-10.

(5) Asakura, R., Iwase, K., Ikeya, T., Takao, M., Kaneto, T., Fujii N., and Ohmori, M., "The Tsunami Wave Force Acting on Land Structures", Proceedings of the 28th International Conference on Coastal Engineering, Cardiff, Wales, (2002), pp. 1191-1202. 